\title{
Askin Tumor
}

National Cancer Institute

\section{Source}

National Cancer Institute. Askin Tumor. NCI Thesaurus. Code C7542.

A primitive neuroectodermal tumor (small round blue cell tumor) of the thorax which can involve the periosteum, thoracic wall and/or pleura though it spares the lung parenchyma. 